\title{
A Framework for Innovating through Design:
}

\author{
Design Attitudes
}

LAURA CLÈRIES

\begin{abstract}
Design has the potential for transformation and innovation. In the current changing and complex environment facing multiple new challenges, the design discipline itself is also changing, being increasingly implicated in less tangible matters. The purpose of design and the role of designers is being redefined, and in this context, which designerly ways of innovating, namely Design Attitudes, do we have to promote in order to have presence in the future? This paper presents the Design Attitudes Trend report as well as a digital Design Attitudes Survey, obtained through the use of a qualitative trends' analysis methodology. The report and survey propose four different ways of innovating, that is, design innovators' types, and an initial exploration of the meaning of the resulting collective survey data collected amongst design professionals and students.
\end{abstract}

KEYWORDS: Innovation through design; design strategy; trends research; design attitudes; impact through design

Design is a discipline that is able to generate impact in many areas. It materializes new ideas and has therefore the potential for innovation. The discipline of design has been traditionally approached into different specialties, such as product design, graphic design, interior design, and so on. In recent years, and driven by the current changing and complex environment, design has been adopting new roles and has expanded its field of action, being also implicated in more strategic responsibilities (Labarrre, 2016). The purpose of design and the role of designers is being redefined (Böninger, 2021), and a new framework for innovating through design needs to be established. How design solves and brings innovation depends on the purpose, on the attitude towards innovation.

Design practice and design education may be positioned and activated to work prospectively and be ahead of current concerns with environmental, social and ethical challenges. Accordingly, tools and techniques originating in futures studies intertwine with design practices offering exploratory, methodological and anticipatory work on how we might shape our futures through design together (Clèries, Morrison, 2020). Qualitative trends research methodologies have been used in design management, practice and education to explore future scenarios and respond to near-future consumer needs (Raymond, 2010). Through these methodologies it is possible to detect patterns that can shed light on directions for innovation through design, identify the type of innovators and also the impact areas. A series of creative profiles and skilled personalities evaluation tests have been previously developed (Belbin, 
1991; Martínez-Villagrasa 2019). In this study case, the purpose is to understand the type of design mindset and type of impact area, somehow to build a Designer's ID, or a designer's identity, more than a personality profile that can apply to other type of disciplines. Identifying these different design attitudes will allow us to foresee how to train the next generation of designers and to create meaningful impact strategies within design management roles.

This article proposes a framework for innovating through design by exploring the attitudes and concepts that shape and define the future role of design and designers through a qualitative trends methodological approach.

\section{Methodology}

This study has been performed using a qualitative trends research methodology as described in (Raymond, 2010), which is a qualitative visual methodology for trends forecasting where it includes design as an area where to spot weak signals of emerging innovations (Evans, 2003). This methodology can be considered as a parallel methodology to the STEEP one (Juselius, 2012), where design is added in the process.

\section{Design Attitudes: Trend report and directions for innovating through design}

The first step of this methodology is to do desk research in order collect qualitative data at global level from secondary sources (local and international high-impact newspapers) tackling the essential information in areas such as economy, politics, environment and technology; as well as performing desk research of emerging designs and designers through the scouting of international specialist paper and digital design magazines such as Viewpoint and Dezeen. Parallel to this desk research, primary field research was undertaken by exploring design projects from emerging designers at design festivals such as Dutch Design Week and Salone del Mobile. All this collected information, stored in a single folder as images and screenshots (over 100 projects and keywords), is printed in the same sized images in order to build an Evidence Wall. Following this display, clustering of concepts and projects was performed using the threetimes rule or cultural triangulation process: clustering of concepts that repeat in at least three different sectors (from fashion up to architecture). This clustering is repeated until a certain critical mass of knowledge is achieved. In this process, and in similarity to other trends research results, four directions for innovation (four large clusters) were identified, namely four Design Attitudes.

Once this process is finalised, further analysis of each directions for innovation was performed: selecting the most relevant design projects, defining the final keywords, analysing the impact areas and identifying the common role of designers. A Design Attitudes Trend Report was generated containing all this information.

\section{Design Attitudes Survey}

An added contribution of this paper is a Design Attitudes Survey, that is built based on the findings of the trend report, in order to use it as a tool both individually and collectively. Individually, so that designers and design professionals can understand their Design Attitude profile combination; collectively, to understand the type of designers' profile that, for instance, a Design University is delivering through their specific positioning and training. In order to build the Design Attitudes Survey, it was identified which transversal indicators were applicable to all the four trends: sustainability, technology, innovation, industry, wellness, tradition, user research, design process, and driver for innovation. It was then defined how each trend, or 
attitude, approached these indicators. Next, a multiple-choice survey using a MS Teams Forms platform template was created, which also included the final multiple-choice question 'what is the role of designers?'. The survey was delivered through an event, the Design Attitudes Forum, that reached an ecosystem of design professors and professionals, as well as design students.

\section{Results and analysis}

\section{Design Attitudes: Trend report and directions for innovating through design}

After analysis through clustering of concepts and projects in the evidence wall, four ways for innovation have been identified and named as four 'design attitudes': four different (but not exclusive) designerly ways of innovating or, in other words, meaningful and creative ways to approach future changes. These are The Conscious, The Engaged, The Resilient and The Rebel. Each Design Attitude is described providing weak signals evidences through examples of design projects.

The first direction for innovation, The Conscious, expresses a will for providing practical and clever solutions that act as daily assistants - the project Food Storage by Friday Project, a food shelf storage designed to emulate the food pyramid, providing high-capacity storage for vegetables an upper low capacity storage for products with high levels of sugar. Or the Morph wheel by Duncan Fitzsimmons, a foldable wheel for wheelchairs. In terms of sustainability, aiming at zero-waste productions, such as the Monobloc brush y Andrey \& Shay or the zerowaste collection by COS, and driven by concepts such as 'Inspired by scarcity', a design research project by Hanae Shimizu. An approach to hybridising crafts with technology (technocraft), in examples such as the 3D tapestry work by Chloe McCormick or the CNC milled leather by Alexander Taylor for Adidas, combining digital technologies such as 3D printing and CNC milling with traditional techniques such as hand-made tapestry. Driven by consumer's need for more transparency in production processes, the Zady company campaign 'Honesty, process, quality matters' exemplifies this turning point for industries to be more open to open towards conscious consumers.

The main impact area for The Conscious attitude is on industry. A new approach to industrial processes is needed, considering the diminishing of resources, the need for transparency and a more conscious take on production. The designer's role is an iteration of the traditional role for designers, to provide practical solutions and meaningful products. This type of innovative designers should exhibit skills such as research, by using tools that bring what is meaningful and relevant to the customers; relevance, to have a customer-value orientation; and self-awareness, providing what is right for the problem and client.

The second direction for innovation, The Engaged, deals with the holistic perspective of design, that considers the emotional dimension of humans - projects that become more intuitive and immersive using colour, such as the Measuring less to feel more by Mickael Boulay, or the ChromaYoga space in London. Products go beyond functionality to offer an emotional and detox experience, with another example such as the Daily Poetry project, a collection of coloured liquid interactive vessels that provide calm. In a will to humanise technology, going beyond the physical metrics of wearables, towards monitoring more mental and neurological metrics that, combined with the right algorithms, provide feedback on the mood state of the user. The user becomes an active part of the final product by personalisation depending on their needs, such in projects like Villa Verde by Alejandro Aravena. The Engaged also deals with inclusive, empathy-driven proposals - projects such as the No country for old men by 
Lanzavecchi + Wai or Redesigning the impatient hospice experience by Fuelfor. Providing gamified experiences such as The silent history app or the Universal construction kit by F.A.T. is also representative of this direction.

The main impact area for The Engaged attitude is on human. In an era of posthumanism, and establishment of technology and robotization in many areas, designers need to approach innovations for humans as individuals on a more holistic level. Human-machine interaction should be taken to another level, providing a more fluid dialogue. These type of innovator's role goes towards the humanistic area of design, understanding the psychological and cognitive constraints that define us. Empathy, imagination, and storytelling become necessary skills to understand users and deliver gamified or holistic products and experiences.

The third direction for innovation, The Resilient, has a systemic thinking approach and considers the hybridisation of knowledge between disciplines. Design collaborates with surgeons to explore ways for patternmaking of clothing (Skinship UK), or with biologists to provide bacteria-driven colour palettes (Faber Futures by Natsai Chieza). Cross-cultural influences provide creative and fresh ways for innovation. Integral and infrastructural projects that consider the physical and digital layers (Nissan Fuel station of the future by Foster \& partners). This direction aims at social innovation through collaborative and participative processes (Participle by Hillary Cottam).

The main impact area for the Resilient attitude is on society as a system. An innovator used to deal with complexity and oversee organizations and systems, and to bridge the physical with the digital layer of any product-service-system. The role for this type of innovator is as a strategist. Collaboration, transferability and visual communication become essential to be able to interact and communicate with different agents, integrate multiple perspectives and transfer ideas from one context to another.

The fourth way for innovation, The Rebel, uses design and creativity to question the established status quo, in projects such as the campaign Where is my $€ 300,00$ by Kesselskramer for Women Inc. Statements that offer alternative ways for manufacturing, such as the maker movement and distributed design market platforms are key in this direction. Approaches to sustainability that propose hacking and repairing or the use of waste as a raw resource. This direction for innovation also proposes spontaneous and non-linear design processes with an experimental focus ( 3 to 5 minutes chair by Jenny Nordberg).

The main impact area for the Rebel attitude is on generating new cultural values. A creative mindset that reflects future cultures and introduces ideas that will conform the collective imaginary. The main role of this type of designer is to be a change agent, be the driver for the introduction of necessary concepts that are, at the beginning, not culturally familiar. Skills such as cultural context \& contextual thinking (citing DMI FuturED (Various, 2021) 'the ability to capture perceptual details and interpret them with larger patterns of cultural meaning'), expression \& persuasion and a maker mentality are decisive for this innovator profile'.

In order to have an overview of each Design Attitude, table 1 provides a summary of the description of each Design attitude, its main impact area, the associated designer's role and a selection of the desirable soft skills for each type of innovator. The soft skills were derived and assigned from the list of the twelve skills identified by the Design Management Institute project FuturED (Various, 2021). 
Table 1: Design attitudes description, main impact area, proposed designers' role and related design skills

\begin{tabular}{|c|c|c|c|c|}
\hline & DESCRIPTION & $\begin{array}{l}\text { MAIN IMPACT } \\
\text { AREA }\end{array}$ & $\begin{array}{l}\text { DESIGNER'S } \\
\text { ROLE }\end{array}$ & SOFT SKILLS \\
\hline $\begin{array}{l}\text { The Con- } \\
\text { scious }\end{array}$ & $\begin{array}{l}\text { is primarily concerned } \\
\text { with practical solutions } \\
\text { and the impact of every- } \\
\text { day design with a focus } \\
\text { on optimising the pro- } \\
\text { duction of everyday } \\
\text { goods. Longing for sim- } \\
\text { pler times and the ab- } \\
\text { sence of the superflu- } \\
\text { ous, he rethinks tradi- } \\
\text { tion by making the } \\
\text { strange familiar. With a } \\
\text { high sense of awareness } \\
\text { on our environment, he } \\
\text { believes in the locally } \\
\text { produced and globally } \\
\text { connected. }\end{array}$ & Industry & $\begin{array}{l}\text { Solution pro- } \\
\text { vider }\end{array}$ & $\begin{array}{l}\text { relevance, } \\
\text { self-aware- } \\
\text { ness, research }\end{array}$ \\
\hline The Engaged & $\begin{array}{l}\text { goes for a human and } \\
\text { holistic perspective and } \\
\text { considers design in all its } \\
\text { dimensions. With a high } \\
\text { sense of creating a feel- } \\
\text { ing of affection, acts in } \\
\text { urban environments and } \\
\text { believes in producing } \\
\text { positive change by em- } \\
\text { powering society, using } \\
\text { a game frame and par- } \\
\text { ticipative mindset }\end{array}$ & Human & Humanist & $\begin{array}{l}\text { imagination, } \\
\text { empathy, sto- } \\
\text { rytelling }\end{array}$ \\
\hline The Resilient & $\begin{array}{l}\text { works at the interplay of } \\
\text { disciplines, fusing vari- } \\
\text { ous ways of thought to } \\
\text { identify new opportuni- } \\
\text { ties for revolutionizing } \\
\text { synergies. A cross-ferti- } \\
\text { liser with a high sense } \\
\text { for adaptation, he is able } \\
\text { to fail, learn and re-cre- } \\
\text { ate new systems. Believ- } \\
\text { ing in design as a collab- } \\
\text { orative system, where } \\
\text { sharing knowledge, mix- } \\
\text { ing identities and the } \\
\text { cultural multiplicity are }\end{array}$ & $\begin{array}{l}\text { Society as a } \\
\text { system }\end{array}$ & Strategist & $\begin{array}{l}\text { collaboration, } \\
\text { transferabil- } \\
\text { ity, visual } \\
\text { communica- } \\
\text { tion }\end{array}$ \\
\hline
\end{tabular}




\begin{tabular}{|c|c|c|c|c|}
\hline & $\begin{array}{l}\text { drivers } \\
\text { for change }\end{array}$ & & & \\
\hline The Rebel & $\begin{array}{l}\text { questions the entire } \\
\text { logic and the ecosystem, } \\
\text { believing that in refer- } \\
\text { ence to resources, con- } \\
\text { sumption and society } \\
\text { old rules no longer work. } \\
\text { With a predominant crit- } \\
\text { ical thinking mindset, } \\
\text { proposes alternative } \\
\text { ways of manufacturing } \\
\text { and consuming, and the } \\
\text { use of design as a tool to } \\
\text { raise social and cultural } \\
\text { awareness. An experi- } \\
\text { mentally driven maker, } \\
\text { he rejects the glossy per- } \\
\text { fection portrayed by so- } \\
\text { cial media }\end{array}$ & $\begin{array}{l}\text { Cultural val- } \\
\text { ues }\end{array}$ & Change agent & $\begin{array}{l}\text { maker men- } \\
\text { tality, cultural } \\
\text { context \& } \\
\text { contextual } \\
\text { thinking, ex- } \\
\text { pression and } \\
\text { persuasion }\end{array}$ \\
\hline
\end{tabular}

\section{Design Attitudes Survey}

The survey was oriented to determine what type of design innovator profiles were displayed in a certain community of design professionals and design students, by determining the percentage of each innovator attitude at collective level. Another objective of this survey was to establish the foundations for the development a quantitative tool to support validation of qualitative trends methodologies.

Table 2.1. and table 2.2. depict the orientation towards each indicator for each design attitude, which was used as the internal information to design the survey template. The survey reached a total data from 113 design professionals and design students.

Table 2.1.: Indicators and design approach depending on the design attitude (I)

\begin{tabular}{|c|c|c|c|c|c|}
\hline & $\begin{array}{l}\text { SUSTAINA- } \\
\text { BILITY }\end{array}$ & $\begin{array}{l}\text { TECHNOL- } \\
\text { OGY }\end{array}$ & $\begin{array}{l}\text { INNOVA- } \\
\text { TION }\end{array}$ & INDUSTRY & WELLNESS \\
\hline Conscious & $\begin{array}{l}\text { minimize } \\
\text { waste }\end{array}$ & efficiency & $\begin{array}{l}\text { in processes } \\
\text { and materi- } \\
\text { als }\end{array}$ & $\begin{array}{l}\text { rethink pro- } \\
\text { cesses }\end{array}$ & functional \\
\hline Engaged & $\begin{array}{l}\text { low con- } \\
\text { sumption }\end{array}$ & $\begin{array}{l}\text { humanisa- } \\
\text { tion }\end{array}$ & $\begin{array}{l}\text { technologi- } \\
\text { cal }\end{array}$ & robotization & holistic \\
\hline Resilient & $\begin{array}{l}\text { share \& re- } \\
\text { use }\end{array}$ & $\begin{array}{l}\text { social em- } \\
\text { powerment }\end{array}$ & social & synergies & social \\
\hline Rebel & $\begin{array}{l}\text { hack \& re- } \\
\text { pair }\end{array}$ & game & cultural & makers & moral \\
\hline
\end{tabular}


Table 2.2.: Indicators and design approach depending on the design attitude (II)

\begin{tabular}{|c|c|c|c|c|c|}
\hline & USER & TRADITION & $\begin{array}{l}\text { DESIGN } \\
\text { PROCESS }\end{array}$ & DRIVE & $\begin{array}{l}\text { DESIGNERS' } \\
\text { ROLE }\end{array}$ \\
\hline Conscious & $\begin{array}{l}\text { market re- } \\
\text { search }\end{array}$ & $\begin{array}{l}\text { hybridise } \\
\text { craftsman- } \\
\text { ship with } \\
\text { new technol- } \\
\text { ogies }\end{array}$ & research & $\begin{array}{l}\text { conscious- } \\
\text { ness }\end{array}$ & $\begin{array}{l}\text { solution pro- } \\
\text { vider }\end{array}$ \\
\hline Engaged & $\begin{array}{l}\text { the user per- } \\
\text { sonalises the } \\
\text { product }\end{array}$ & inspiration & storytelling & empathy & humanist \\
\hline Resilient & $\begin{array}{l}\text { the user as } \\
\text { co-designer }\end{array}$ & $\begin{array}{l}\text { cultural mul- } \\
\text { tiplicity }\end{array}$ & $\begin{array}{l}\text { collabora- } \\
\text { tion }\end{array}$ & adaptation & strategist \\
\hline Rebel & $\begin{array}{l}\text { intervene in } \\
\text { the collec- } \\
\text { tive imagi- } \\
\text { nary }\end{array}$ & $\begin{array}{l}\text { start from } \\
\text { scratch a } \\
\text { new crafts- } \\
\text { manship }\end{array}$ & $\begin{array}{l}\text { experimen- } \\
\text { tation }\end{array}$ & $\begin{array}{l}\text { critical think- } \\
\text { ing }\end{array}$ & $\begin{array}{l}\text { change } \\
\text { agent }\end{array}$ \\
\hline
\end{tabular}

The survey offered these options in a multiple-choice format and, by selecting one of the four options for each indicator, the design professionals and design students were defining their orientation or attitude towards each indicator. Once the survey was completed, an algorithm calculated the final percentage for each attitude for each individual and as a collective result.

The collective result, which maps then the Design Attitude of the group, is detailed in Table 3. An overall consideration of the values is that all four attitudes are quite balanced, meaning that all four attitudes are present. Considering that The Conscious direction accounts for $28 \%$ of the result, we can elucidate that the design university still has a traditional, but updated, approach to design where sustainability is about minimizing waste, innovation focuses on improving the efficiency of processes and materials resources, traditional craftsmanship bridges with digital technologies, and wellness has a functional angle. A $22 \%$ of this community display an Engaged design attitude, meaning that probably the more engineering side of the university is focusing on humanising technology, providing holistic wellness and the option for users to personalise their product, while at the same time understanding that innovation is about technology and probably the robotization of industrial processes. An elevated percentage of this collective displayed a Resilient attitude, accounting for the $29 \%$. This means that the design university is including a high level of social innovation focus, where industry is about creating consortiums and synergies of knowledge, the user becomes co-creator and sharing \& reusing is the way forward to sustainable systems. A slightly lower percentage, $17 \%$, is for Rebel attitudes, so we can conclude that design professionals and students also exhibit a critical thinking approach as art students and artist do.

Table 3: Survey results: Collective percentage of Conscious, Engaged, Resilient and Rebel attitudes

\begin{tabular}{ll}
\hline DESIGN ATTITUDE TYPE & $\%$ \\
\hline Conscious & 28 \\
\hline Engaged & 22 \\
\hline Resilient & 29 \\
\hline Rebel & 17 \\
\hline$* n=113$ (Professionals and students from Design University)
\end{tabular}

66

A Framework for Innovating through Design

Futures of Education, Culture \& Nature - Learning to Become 
Another way of analyzing the gathered data is to understand how the different options for each indicator, relative to the attitude, are distributed. Table 4.1 and 4.2 and depicted as the pie charts in Figure 1, present the results of the breakdown of the percentages of responses relative to each indicator. Again, results are quite well-balanced and indicate that mainly all indicators' responses can be considered as relevant. Only at the questions, 'What is your approach to Technology?', 'What is your approach to Wellness?', and 'What is your approach to Tradition?', the respective responses 'game', 'moral', and 'start from scratch a new craftsmanship', do not seem to be that relevant since the percentages are quite low. On the other hand, by taking into account the main percentages for the indicators provide a more detailed mapping and a descriptive of the Design Attitudes characteristics of the studied design students and design professionals:

- In terms of Sustainability, the main attitudes - almost equally important- are to minimize waste and share \& reuse;

- In terms of Technology, the main attitudes are efficiency and social empowerment;

- In terms of Innovation, the main attitudes are technological innovation and innovation in processes and materials;

- In terms of Industry, the main attitudes are to rethink processes, establish synergies and the maker movement;

- In terms of Wellness, the main attitudes are holistic and social wellness;

- In terms of User, the main attitudes are to integrate the user as co-designer, and to influence on the collective imaginary;

- In terms of Tradition, the main attitudes are to hybridise craftsmanship with new technologies, use it as inspiration, and using tradition as cultural multiplicity;

- In terms of User, the main attitudes are to integrate the user as co-designer, and to influence on the collective imaginary;

- In terms of Design Process, the main attitudes are research, collaboration and experimentation;

- and finally, in terms of Drive for designing, the main attitudes are empathy and critical thinking.

Table 4.1.: Percentages of indicators relative to each attitude $(I)-n=103$

\begin{tabular}{|c|c|c|c|c|c|c|c|c|c|c|}
\hline & $\begin{array}{l}\text { SUSTAINA- } \\
\text { BILITY }\end{array}$ & $\begin{array}{l}\mathrm{S} \\
\%\end{array}$ & $\begin{array}{l}\text { TECHNOL- } \\
\text { OGY }\end{array}$ & $\begin{array}{l}\mathrm{T} \\
\% \\
\end{array}$ & INNOVATION & $\begin{array}{l}\text { INN } \\
\%\end{array}$ & INDUSTRY & $\begin{array}{l}\text { IN } \\
\mathrm{D} \%\end{array}$ & $\begin{array}{l}\text { WELL- } \\
\text { NESS }\end{array}$ & $\begin{array}{l}W \\
\%\end{array}$ \\
\hline $\begin{array}{l}\text { Con- } \\
\text { scious }\end{array}$ & $\begin{array}{l}\text { minimize } \\
\text { waste }\end{array}$ & $\begin{array}{l}3 \\
9\end{array}$ & efficiency & $\begin{array}{l}5 \\
0\end{array}$ & $\begin{array}{l}\text { in pro- } \\
\text { cesses and } \\
\text { materials }\end{array}$ & 37 & $\begin{array}{l}\text { rethink } \\
\text { pro- } \\
\text { cesses }\end{array}$ & 28 & $\begin{array}{l}\text { func- } \\
\text { tional }\end{array}$ & 17 \\
\hline $\begin{array}{l}\text { En- } \\
\text { gaged }\end{array}$ & $\begin{array}{l}\text { low con- } \\
\text { sumption }\end{array}$ & $\begin{array}{l}1 \\
4\end{array}$ & $\begin{array}{l}\text { humanisa- } \\
\text { tion }\end{array}$ & $\begin{array}{l}1 \\
7\end{array}$ & $\begin{array}{l}\text { technologi- } \\
\text { cal }\end{array}$ & 32 & $\begin{array}{l}\text { robotiza- } \\
\text { tion }\end{array}$ & 17 & holistic & 34 \\
\hline $\begin{array}{l}\text { Resili- } \\
\text { ent }\end{array}$ & $\begin{array}{l}\text { share \& re- } \\
\text { use }\end{array}$ & $\begin{array}{l}3 \\
9\end{array}$ & $\begin{array}{l}\text { social em- } \\
\text { power- } \\
\text { ment } \\
\end{array}$ & $\begin{array}{l}2 \\
7\end{array}$ & social & 18 & $\begin{array}{l}\text { syner- } \\
\text { gies }\end{array}$ & 27 & social & 43 \\
\hline Rebel & $\begin{array}{l}\text { hack \& re- } \\
\text { pair }\end{array}$ & 9 & game & 6 & cultural & 13 & makers & 28 & moral & 7 \\
\hline
\end{tabular}


Table 4.1.: Percentages of indicators relative to each attitude (II) $-\mathrm{n}=103$

\begin{tabular}{|c|c|c|c|c|c|c|c|c|}
\hline & USER & U\% & TRADITION & T\% & $\begin{array}{l}\text { DESIGN PRO- } \\
\text { CESS }\end{array}$ & DP\% & DRIVE & $\begin{array}{l}\mathrm{D} \\
\%\end{array}$ \\
\hline $\begin{array}{l}\text { Con- } \\
\text { scious }\end{array}$ & $\begin{array}{l}\text { market re- } \\
\text { search }\end{array}$ & 16 & $\begin{array}{l}\text { hybridise } \\
\text { craftsmanship } \\
\text { with new } \\
\text { technologies }\end{array}$ & 26 & research & 32 & $\begin{array}{l}\text { conscious- } \\
\text { ness }\end{array}$ & $\begin{array}{l}1 \\
6\end{array}$ \\
\hline Engaged & $\begin{array}{l}\text { the user } \\
\text { personalises } \\
\text { the product }\end{array}$ & 17 & inspiration & 33 & storytelling & 14 & empathy & $\begin{array}{l}4 \\
1\end{array}$ \\
\hline Resilient & $\begin{array}{l}\text { the user as } \\
\text { co-designer }\end{array}$ & 41 & $\begin{array}{l}\text { cultural multi- } \\
\text { plicity }\end{array}$ & 34 & collaboration & 27 & adaptation & $\begin{array}{l}1 \\
7 \\
\end{array}$ \\
\hline Rebel & $\begin{array}{l}\text { intervene in } \\
\text { the collec- } \\
\text { tive imagi- } \\
\text { nary }\end{array}$ & 27 & $\begin{array}{l}\text { start from } \\
\text { scratch a new } \\
\text { craftsmanship }\end{array}$ & 7 & $\begin{array}{l}\text { experimenta- } \\
\text { tion }\end{array}$ & 27 & $\begin{array}{l}\text { critical think- } \\
\text { ing }\end{array}$ & $\begin{array}{l}2 \\
6\end{array}$ \\
\hline
\end{tabular}

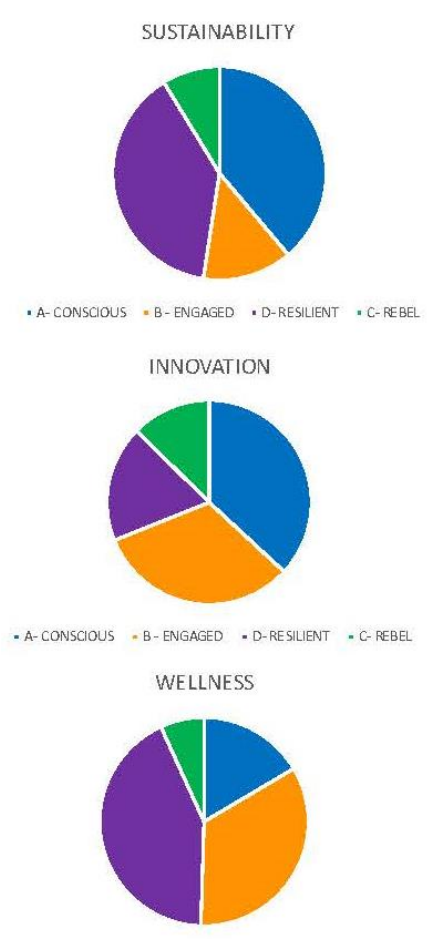

- A CONSCIOUS - B-ENGAGED - D-RESLLENT - C- REBEL
TECHNOLOGY

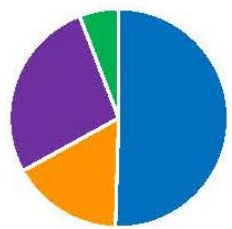

- a conscious - b-engaged - D-Resillent - C-Rebel INDUSTRY

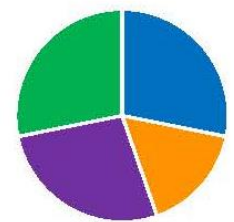

- a-consclous = B-engaged - D-resilient * C-Rebel USER

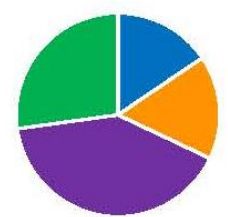

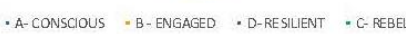

DESIGN PROCESS

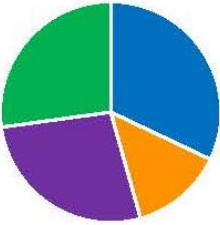

- a conscious - B-engafed - d-resilient - C-rebel TRADITION

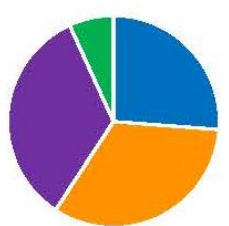

- A-conscious - B-engaged - D-resilient - C-rebel DRIVE

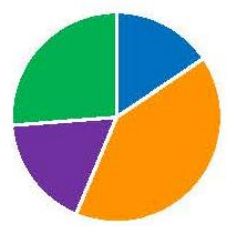

- a CONSCIOUS - B-ENGAED - D-RESLLIENT * C-REBe

Figure 1 - Pie charts of the percentages of indicators relative to each attitude.

Another third interesting result can be derived from the interpretation of data on the opinion of design professionals and students towards their role as designers, be it either solution provider, humanist, strategist or change agent. Table 5 shows the segmented results that offer a glimpse on the future role of designers.

The results are quite balanced between professionals and students and, surprisingly enough, the community strongly believes designers' role is to be change agents, with an 
average of $56 \%$. The community still does not perceive designers to be strategists, with only $8 \%$ of the design professionals and none of the design students supporting this option.

Table 5: Survey results: Perception of the role of designers (by Design Professionals and Design Students)

\begin{tabular}{lll}
\hline ROLE OF DESIGNERS & \% (Professionals) & \% (Students) \\
\hline Solution providers & 27 & 35 \\
\hline Humanists & 11 & 9 \\
\hline Strategists & 8 & 0 \\
\hline Change agents & 54 & 57 \\
\hline
\end{tabular}

$* n=90$ Professionals and $n=23$ students from Design University

\section{Conclusions}

Four Design Attitude profiles, with their description and impact areas, have been developed. These attitudes, or Designers' Identities, packed as a trend report and as a digital survey tool, offer a tool to explore the training of future design professionals and the positioning of the design practise. As further development to this research, more statistical analysis on the generated data of the survey would be interesting in order to get deeper conclusions and to also explore the open question answers by the participants. Further research in the direction of validating the tool will be needed, by also enlarging the number of survey participants towards an international community. The Design Attitudes Survey tool is currently being used in final degree projects by design students in order to frame their skills, and their orientation towards innovation. This will add up information on the validity of this trend report, of the survey tool, and will open paths for curriculum development. Another way for enlarging this research is to adapt the survey to a design management context, in order to understand how individuals within a company innovate and how companies position themselves.

\section{Literature}

Clèries, L., Morrison, A. Design Futures Now: Literacies \& Making. (2020) Temes de Disseny. Num. 36, pp. 8-15.

Böninger C., Frenkler F., Schmidhuber S. (2021). Designing Design Education. White Book on the Future of Design Education. Germany: IF Foundation.

Labarre, S. (2016). The most important design jobs of the future. FastcoDesign. Retrieved from https://www.fastcompany.com/3054433/the-most-important-design-jobs-of-the-future

Meredith Belbin, R. (1991). Design Innovation and the team. Design Management Journal Vol. 2 No. 3.

Martínez Villagrasa, B., Esparza D., and Cortiñas, S. (2019). Creative Competencies: Between Practice and Education in Design." The International Journal of Design Education 13(3): 2738.

Evans M. (2003). Trend Forecasting for Design Futures. Conference Paper presented the Techné's strategic nature Conference.

Juselius, P. (2012) Exploration to trends \& product developmenta framework to guide trend \& consumer driven concept development. Master of arts thesis. Aalto University School of Art, Design and A rchitectur Department of Design Degree programme of applied arts and design. 
Raymond, M. (2010). The trend forecaster's handbook. London: Laurence King Publishing.

Various. Design Management Institute FuturED project. (2021). Retrieved from https://www.dmi.org/page/futurED 